Am. J. Nephrol. 1987;7:I-VI

\title{
Contents, Vol. 7, 1987
}

\section{American ${ }^{\wedge}$ Journal of}

\section{Editor-in-Chief Editorial Board}

Shaul G. Massry, Los Angeles, California Christine Abrass, Seattle, Washington

Zalman S. Agus, Philadelphia, Pennsylvania

Assistant Editor Robert J. Anderson, Denver, Colorado

Vito M. Campese, Los Angeles, California Jose A.L. Arruda, Chicago, Illinois

William M. Bennett, Portland, Oregon

Managing Editor Geoffrey M. Berlyne, Brooklyn, New York

Mary Benson, Los Angeles, California Christopher R. Blagg, Seattle, Washington

Jacques J. Bourgoignie, Miami, Florida

Associate Editors John Bower, Jackson, Mississippi

Neal S. Bricker, Loma Linda, California Barry M. Brenner, Boston, Massachusetts

Arthur H. Cohen, Torrance, California Ruth E. Bulger, Houston, Texas

(Renal Pathology Forum) Russell W. Chesney, Madison, Wisconsin

Garabed Eknoyan, Houston, Texas Fredric L. Coe, Chicago, Illinois

(Medical Art and History of Nephrology) Ralph A. De Fronzo, New Haven, Connecticut

Eben I. Feinstein, Los Angeles, California Murray Epstein, Miami, Florida

(Nephrology Consultant Section) Richard N. Fine, Los Angeles, California

Eli A. Friedman, Brooklyn, New York Richard J. Glassock, Torrance, California

Neil A. Kurtzman, Lubbock, Texas Jared J. Grantham, Kansas City, Kansas

(Quiz of the Month Section) Ronald D. Guttmann, Montreal, Canada

Robert W. Schrier, Denver, Colorado John P. Hayslett, New Haven, Connecticut

Wadi N. Suki, Houston, Texas Lee W. Henderson, San Diego, California

(Editorials and Reviews Section) Robert H. Heptinstall, Baltimore, Maryland

Robert L. Vernier, Minneapolis, Minnesota George J. Kaloyanides, Long Island, New York

(Pediatric Forum Section) Norman M. Kaplan, Dallas, Texas

Adrian I. Katz, Chicago, Illinois

Michael Kaye, Montreal, Canada

Carl M. Kjellstrand, Minneapolis, Minnesota

Saulo Klahr, St. Louis, Missouri

Charles R. Kleeman, Los Angeles, California

Juha P. Kokko, Dallas, Texas

Joel D. Kopple, Los Angeles, California

Joseph M. Letteri, East Meadow, New York

Robert G. Luke, Birmingham, Alabama

John F. Maher, Bethesda, Maryland

Manuel Martinez-Maldonado, San Juan, Puerto Rico

Franklin D. McDonald, Detroit, Michigan 
Alfred F. Michael, Minneapolis, Minnesota

John S. Najarian, Minneapolis, Minnesota

Karl D. Nolph, Columbia, Missouri

Donald E. Oken, Richmond, Virginia

Victor E. Pollak, Cincinnati, Ohio

Jules B. Puschett, Pittsburgh, Pennsylvania

Floyd C. Rector, San Francisco, California

Jay H. Stein, San Antonio, Texas

Philip R. Steinmetz, Farmington, Conn.

Richard L. Tannen, Ann Arbor, Michigan

Craig C. Tisher, Gainsville, Florida

Curtis B. Wilson, La Jolla, California

S. Karger · Medical and Scientific Publishers $\cdot$ Basel $\cdot$ München · Paris $\cdot$ London · New York New Delhi — Singapore $\square$ Tokyo · Sydney

Drug Dosage

The authors and the publisher have exerted every effort to ensure that drug selection and dosage set forth in this text are in accord with current recommendations and practice at the time of publication. However, in view of ongoing research, changes in government regulations, and the constant flow of information relating to drug therapy and drug reactions, the reader is urged to check the package insert for each drug for any change in indications and dosage and for added warnings and precautions. This is particularly important when the recommended agent is a new and/or infrequently employed drug.

All rights reserved.

No part of this publication may be translated into other languages, reproduced or utilized in any form or by any means, electronic or mechanical, including photocopying, recording, microcopying, or by any information storage and retrieval system, without permission in writing from the publisher or, in the case of photocopying, direct payment of a specified fee to the Copyright Clearance Center (see 'Information for Readers and Subscribers').

(C) Copyright 1987 by S. Karger AG, P.O. Box, CH-4009 Basel (Switzerland) Printed in

Switzerland by Graphische Anstalt Schüler AG, Biel

Contents Vol. 7,1987

No.1

Editorial

Renal Complications in Patients with the Acquired Immune

Deficiency Syndrome (AIDS)

Humphreys, M.H.; Schoenfeld, P.Y 1

Clinical Studies

Prediction of Outcome in Acute Renal Failure

Corwin, H.L.; Teplick, R.S.; Schreiber, M.J.; Fang, L.S.T.;

Bonventre, J.V.; Coggins, C.H

8

Paucity of Minimal-Change Lesion in Children with Early Frequently Relapsing Steroid-

Responsive Nephrotic Syndrome

Trachtman, H.; Carroll, F.; Phadke, K.; Khawar, M.;

Nicastri, A,; Chen, C.K.; Tejani, A 13 
Rheological Abnormalities of Erythrocyte Deformability and Increased Glycosylation of Hemoglobin in the Nephrotic Syndrome Cecchin, E.; De Marchi, S.; Panarello, G.; De Angelis, V.. 18

Relapses of Idiopathic Diffuse Crescentic Glomerulonephritis

without Immune Deposits: Report of 6 Cases

Belghiti, D.; Levy, Y.; Rifle, G.; Ottavioli, J.-N.; Ricke-

lynck, J.-P.; Wolf, C; Chalopin, J.-M.; Sobel, A 22

Risk of Iron Overload and 'Hemochromatosis Allele(s)' in

Patients on Maintenance Hemodialysis

Taccone-Gallucci, M.; Di Nucci, G.; Meloni, C; Mariani, G.; Valeri, M.; Piazza, A.; Elia, L; Torromeo, C; Mandelli,

F.; Casciani, C.U 28

Effect of High-Dose Aldosterone Infusions on Renal Electrolyte Excretion in Patients with Renal Insufficiency Hené, R.J.; Koomans, H.A.; Boer, P.; Dorhout Mees, E.J. 33

Successful Treatment of Pseudomonas Peritonitis during Continuous Ambulatory Peritoneal

Dialysis Nguyen, V.; Swartz, R.D.; Reynolds, J.; Wilson, D.; Port, F.K. 38

Case Reports

Unilateral Nodular Diabetic Glomerulosclerosis: Recurrence

of an Experiment of Nature

Béroniade, V.C.; Lefebvre, R.; Falardeau, P 55

Recurrent Hemolytic Uremic Syndrome and Metastatic Malignancy

Sennesael, J.J.; Vanden Houte, K.M.; Spapen, H.D.;

Bruyne, R.M.G. de; Verbeelen, D.L 60

Does Defective Chloride Reabsorption at the Loop of Henle Play a Major Role in the

Pathogenesis of Bartter's Syndrome? Milani, L.; Pessina, A.C.; Maccà, F.; Pauletto, P.; Gatta, A.

65

Letters to the Editor

Glomerulonephritis with Absent Glomerular Basement Mem

brane Antigens and No Family History of Renal Diseases

Hara, M.; Asada, R.; Miura, I.K.; Mase, D.; Higuchi, A.;

Tanizawa, T.; Okada, T 69

Systemic Vasculitis Resembling Periarteritis Nodosa in the

Lupus-Like Syndrome Induced by Hydralazine

Martinez-Vea, A.; Ferrer, I.; Carcía, C; Mayayo, E.; Oliver,

J.A.; Richart, C 71

Treatment of Idiopathic Membranous Nephropathy Unre

sponsive to Methylprednisolone and Chlorambucil with

Cyclosporin

DeSanto, N.G.; Capodicasa, G.; Giordano, C 74

Nephrology Consultant

Nephrotic Syndrome in a Woman with Diabetes mellitus and

Rheumatoid Arthritis

Feinstein, E.; Akmal, M.; Green, R.; Koss, M

Quiz of the Month, Answers 84

Announcements 83 
Quiz of the Month, Questions 44

History of Nephrology

Early Patent and Proprietary Medicines and the Treatment of

Kidney and Urinary Tract Diseases

Cunningham, E.E 45

Ethical Issues in Nephrology

Kidney Donation: Reflections

Spital, A.; Spital, M 49

No. 2

Clinical Studies

Fc-Receptor Function of the Mononuclear Phagocyte System in Glomerulonephritis Secondary to Some Multisystem Diseases

Roccatello, D.; Coppo, R.; Martina, G; Rollino, C; Basolo, B.; Frattasio, C; Fasano, M.E.; Amoroso, A.; Picciotto, G.;

Bajardi, P.; Cordonnier, D.; Piccoli, G

85

IV

Contents

Effects of Naloxone Administration on Endocrine Abnormali ties in Chronic Renal Failure

Grzeszczak, W.; Kokot, F.; Dulawa, J

93

Temporal Profile of Serum Potassium Concentration in Non-

diabetic and Diabetic Outpatients on Chronic Dialysis

Tzamaloukas, A.H.; Avasthi, P.S 101

Prognosis of the Nephrotic Syndrome in Sickle Glomerulopa-thy. A Retrospective Study

Bakir, A.A.; Hathiwala, S.C.; Ainis, H.; Hryhorczuk, D.O.;

Rhee, H.L.; Levy, P.S.; Dunea, G 110

Induction of Peritoneal Fluid Eosinophilia and/or Monocyto-sis by Intraperitoneal Air Injection

Daugirdas, J.T.; Leehey, D.J.; Popli, S.; Hoffman, W.;

Zayas, L; Gandhi, V.C.; Ing, T.S 116

Effect of Dialyzer Geometry on Granulocyte and Complement

Activation

Schaefer, R.M.; Heidland, A.; Hörl, W.H 121

Laboratory Investigation

Evidence for Reduced Catabolism by the Antiglucocorticoid RU 38486 in Acutely Uremic Rats

Schaefer, R.M.; Teschner, M.; Kulzer, P.; Leibold, J.;

Peter, G.; Heidland, A 127

Quiz of the Month, Questions 132

History of Nephrology

Nephrologic Beginnings: The Kidney in the Age of Ibn Sina

(980-1037 AD)

Mujais, S.K 133

Case Reports

Henoch-Schönlein Purpura Complicating Staphylococcal Endocarditis in a Heroin Addict 
Montoliu, J.; Miró, J.M.; Campistol, J.M.; Trilla, A.;

Mensa, J.; Torras, A.; Revert, L 137

Diffuse Intrapulmonary Hemorrhage and Renal Failure in Adult Henoch-Schönlein Purpura

Shichiri, M.; Tsutsumi, K.; Yamamoto, I.; Ida, T.; Iwa-

moto, $\mathrm{H} \quad 140$

Recurrent Membranoproliferative Glomerulonephritis Type 1 in Successive Renal Transplants

Glicklich, D.; Matas, A.J.; Sablay, L.B.; Senitzer, D.; Tellis,

V.A.; Soberman, R.; Veith, F.J 143

Renal Physiology Seminars

Mechanisms and Regulation of Renal $\mathrm{H}+$ and $\mathrm{HCO}^{\wedge}$ Trans

port

Breyer, M.D.; Jacobson, H.R 150

Letters to the Editor

Systemic Amyloidosis in a Chronic Hemodialysis Patient

Oliet, A.; Andres, A.; Praga, M 162

Cholesterol Atheroembolic Renal Disease with Necrotizing

Glomerulonephritis

Rémy, P.; Jacquot, C; Nochy, D.; d'Auzac, C; Yéni, P.;

Bariéty, J 164

Clinicopathological Associations in Mesangial IgA Nephrop-

athy

Bennett, W.M.; Nicholls, K.; Kincaid-Smith, P 166

Quiz of the Month, Answers 168

Announcements 168

No. 3

Clinical Studies

Serum and Peritoneal Fluid Amylase Levels in CAPD. Normal Values and Clinical Usefulness

Caruana, R.J.; Burkart, J.; Segraves, D.; Smallwood, S.;

Haymore, J.; Disher, B 169

Eosinophilia in the Diagnosis of Atheroembolic Renal Disease

Kasinath, B.S.; Corwin, H.L.; Bidani, A.K.; Korbet, S.M.;

Schwartz, M.M.; Lewis, E.J 173

An Increase in Circulating IgA Antibodies to Gliadin in IgA Mesangial Glomerulonephritis

Laurent, J.; Branellec, A.; Heslan, J.-M.; Rostoker, G.;

Bruneau, C; Andre, C; Intrator, L.; Lagrue, G 178

Low Output Left Ventricular Failure in End-Stage Renal Disease

Parfrey, P.S.; Harnett, J.D.; Griffiths, S.; Gault, M.H.;

Barre, P.E.; Guttmann, R.D 184

Diagnosis of Hypothyroidism in Patients with End-Stage Re

nal Disease

Tang, W.W.; Kaptein, E.M.; Massry, S.G 192

Diclofenac, a Nonsteroidal Anti-Inflammatory Drug, De

creases Proteinuria in Some Glomerular Diseases: A Con

trolled Study

Laurent, J.; Belghiti, D.; Bruneau, C; Lagrue, G 198 
Noninvasive Diagnosis of Uremic Osteodystrophy: Uses and Limitations Heaf, J.G.; Joffe, P.;

Pødenphant, J.; Andersen, J.R. ... 203

Eicosanoids of Platelets and Vascular Wall in Chronic Renal

Insufficiency

Sinzinger, H.; Leithner, C 212

Polycythaemia following Renal Transplantation: An Association with Azathioprine Dosage?

Webb, D.B.; Price, K.A.; Hutton, R.D.; Newcombe, R.G.;

Salaman, J.R.; Orchard, J 221

Medical Art 226

Quiz of the Month, Questions227

Laboratory Investigation

Beneficial Effects of Atrial Natriuretic Factor on Cisplatin-

Induced Acute Renal Failure in the Rat

Capasso, G.; Anastasio, P.; Giordano, D.; Albarano, L.;

De Santo, N.G228

Case Reports

Poststreptococcal Glomerulonephritis in the Elderly. Report of a Case and Review of the

Literature Melby, P.C.; Musick, W.D.; Luger, A.M.; Khanna, R. . 235

Contents

$\mathrm{V}$

Pseudonecrotizing Fasciitis due to Dialysate and Air Leak in a

Peritoneal Dialysis Patient

Graves, J.; Cella, C; Peacock, J.E., Jr.; Plonk, G

241

Nephrology Consultant

Proteinuria, Hypertension and Renal Failure in a Patient with

Unilateral Renal Agenesis

Maschio, G.; Rugiu, C.; Oldrizzi, L.; Lupo, A

Letter to the Editor

Renal Tubular Vacuolization in a Cyclosporine-A-Treated Re

nal Transplant Patient without Evidence of Cyclosporine A

Nephrotoxicity

Verani, R 250

Quiz of the Month, Answers 252

Quiz of the Month, Questions 303

Ethical Issues in Nephrology

Physicians' Non-Compliance with Patients' Refusal of Life-

Sustaining Treatment

Kaye, M.; Bourgouin, P.; Low, G 304

Case Reports

Nitroprusside-Induced Acute Azotemia

Reid, G.M.; Muther, R.S 313

Involvement of Renal Allograft by Fabry's Disease

Popli, S.; Molnar, Z.V.; Leehey, D.J.; Daugirdas, J.T.;

Roth, D.A.; Adams, M.B.; Cheng, J.-C; Ing, T.S 316 
Membranoproliferative Glomerulonephritis Associated with Chronic Hepatitis B in Adults: Pathogenetic Role of HBsAG Iida, H.; Izumino, K.; Asaka, M.; Kameyama, T.; Takata, M.; Mizumura, Y.; Sasayama, S 319

Medical Art 325

No. 4

Editorial

Growth Retardation in Childhood Renal Disease: A Hor monal or Nutritional Problem?

Chesney, R.W 253

Clinical Studies

Dietary Factors and Medullary Sponge Kidneys as Causes of the So-Called Idiopathic Renal Leak of Calcium

Jaeger, P.; Portmann, L.; Ginalski, J.-M.; Campiche, M.;

Burckhardt, P 257

Plasma Volume Changes Induced by Hypertonic Hemodiafiltration and Standard Hemodialysis

Basile, C; Coates, J.E.; Ulan, R.A 264

Pharmacokinetics of Intravenous Trimethoprim-Sulfamethoxazole during Hemodialysis

Nissenson, A.R.; Wilson, C; Holazo, A 270

IgM Nephropathy: Morphological Study Related to Clinical Findings

Kopolovic, J.; Shvil, Y.; Pomeranz, A.; Ron, N.; Rubinger,

D.; Oren, R 275

Implications of Hypervitaminosis A on the Calcium-Phosphate Metabolism and on Blood Lipids in Hemodialysis Praga, M.; Diaz Rubio, P.; Morales, J.M.; Cañizares, F.; Ruilope, L.M.;

Gutierrez-Millet, V.; Nieto, J.; Rodicio, J.L. 281

Prevention of Posttransplant Acute Tubular Necrosis by the

Calcium Antagonist Diltiazem: A Prospective Random

ized Study

Wagner, K.; Albrecht, S.; Neumayer, H.-H 287

Serum Amylases in Chronic and End-Stage Renal Failure: Ef

fects of Mode of Therapy, Race, Diabetes and Peritonitis

Bastani, B.; Mifflin, T.E.; Lovell, M.A.; Westervelt, F.B.;

Bruns, D.E 292

Digoxin-Like Immunoreactive Substance in Chronic Hemodi

alysis Patients: Effect on Digitoxin Radioimmunoassay

Walker, J.A.; Bialy, G.B.; Cronin Walker, V.; Sherman,

R.A.; Eisinger, R.P 300

Letters to the Editor

Gallium Scan in the Follow-Up of Sarcoid Granulomatous Nephritis

Pagniez, D.C.; MacNamara, E.; Beuscart, R.; Wambergue,

F.; DeQuiedt, P.; Tacquet, A 326 
A Simple Method for Utilizing Frozen Bioptical Kidney Tis

sue for Light Microscopy

Pasquariello, A.; Moriconi, L 328

Renal Pathology Forum

Two Cases of Acute Renal Failure of Unknown Etiology . . 330

Quiz of the Month, Answers 336

No. 5

Editorial

Acetate Metabolism during Hemodialysis: Metabolic Considerations

Vinay, P.; Cardoso, M.; Tejedor, A.; Prud'homme, M.;

Levelillee, M.; Vinet, B.; Courteau, M.; Gougoux, A.;

Rengel, M.; Lapierre, L.; Piette, Y 337

Clinical Studies

False-Positive Digoxin Measurements due to Conjugated Metabolite Accumulation in Combined Renal and Hepatic Dysfunction

Vlasses, P.H.; Besarab, A.; Lottes, S.R.; Conner, D.P.;

Green, P.J.; Gault, M.H 355

Renal Potassium Handling during States of Low Aldosterone Bio-Activity: A Method to

Differentiate Renal and Non-Renal Causes

Zettle, R.M.; West, M.L.; Josse, R.G.; Richardson, R.M.A.;

Marsden, P.A.; Halperin, M.L 360

VI

Contents

Renal Transplantation in Systemic Lupus erythematosus: One

Center's Experience

Roth, D.; Milgrom, M.; Esquenazi, V.; Strauss, J.; Zille-

ruelo, G.; Miller, J 367

Localization of Autonomic Nervous System Dysfunction in

Dialysis Patients

Nakashima, Y.; Fouad, F.M.; Nakamoto, S.; Textor, S.C.;

Bravo, E.L.; Tarazi, R.C 375

Primary Renal Artery Dissection. Presentation of Two Cases

and Brief Review of the Literature

Béroniade, V.; Roy, P.; Froment, D.; Pison, C 382

Visceral Involvement of Dialysis Amyloidosis

Campistol, J.M.; Cases, A.; Torras, A.; Soler, M.; Muñoz-

Gómez, J.; Montoliu, J.; López-Pedret, J.; Revert, L. . 390 Severe Hypertensive Retinopathy.

Increased Incidence in Re-

noparenchymal Hypertension

Heidbreder, E.; Hüller, U.; Schäfer, B.; Heidland, A. . . 394

Medical Art 401

Case Reports

Meningitis due to Campylobacter fetus intestinalis in a Kidney

Transplant Recipient. A Case Report

Rao, K.V.; Ralston, R.A 402 
Tuberculous Arthritis in a Hemodialysis Patient

Haskell, L.P.; Tannenberg, A.M 404

Renal Physiology Seminars

Renal Physiology of the Prostaglandins and the Effects of Non-

steroidal Anti-Inflammatory Agents on the Kidney

Hart, D.; Lifschitz, M.D 408

Letter to the Editor

Is Acute Hepatic Necrosis a Cause of Hyperkalemia?

Campistol, J.M.; Calvet, X.; Montoliu, J.; Bañares, R.;

Revert, L 419

Announcements $\quad 420$

No, 6

Editorial

Significance of Tubulointerstitial Changes in the Renal Cortex

for the Excretory Function and Concentration Ability of

the Kidney: A Morphometric Contribution

Bohle, A.; Mackensen-Haen, S.; Gise, H. v 421

Long-Standing Spontaneous Clinical Remission and Glomeru

lar Improvement in Primary IgA Nephropathy (Berger's

Disease)

Costa, R.S.; Droz, D.; Noel, L.H 440

Percutaneous Transcatheter Recanalization in the Manage ment of Acute Renal Failure due to Sudden Occlusion of the Renal Artery to a Solitary Kidney

Kadir, S.; Watson, A.; Burrow, C 445

Reduced Glomerular Filtration Rate Can Maintain a Rise in

Plasma Bicarbonate Concentration in Humans

Vaz Carneiro, A.; Sebastian, A.; Cogan, M.G

Renal Dysfunction in Brazilian Lead Workers

Pinto de Almeida, A.R.; Carvalho, F.M.; Galvão Spinola,

A.; Rocha, $\mathrm{H} 455$

Distinct Distribution of Periarticular Erosions of the Bones of the Hand in Chronic Renal Failure

Gerber, B.; Horber, F.F.; Robotti, G.; Scheidegger, J.R.;

Frey, F.J 459

Quiz of the Month, Questions 464

Medical Art 465

Case Reports

Effect of Parathyroidectomy on Respiratory Muscle Strength

in Uremic Myopathy

Gómez-Fernández, P.; Sanchez Agudo, L.; Miguel, J.L.;

Almaraz, M.; Vila Dupla, M.J 466

Hypocomplementemic Glomerulonephritis in an Infant and

Mother. Evidence for an Abnormal Form of C3

Linshaw, M.A.; Bruder Stapleton, F.; Cuppage, F.E.; For-

ristal, J.; West, CD.; Schreiber, R.D.; Wilson, C.B. ... 470 Hemodialysis-Associated Acute

Subdural Hematoma. Interim 
Management with Peritoneal Dialysis

Tietjen, D.P.; Moore, J., Jr.; Gouge, S.F 478

Nephrology Consultant

Nephrotic Syndrome and Renal Failure in an Elderly Man

Zawada, E.T., Jr.; Jensen, R.; Hicks, D.; Putnam, W.D.;

Ramirez, G 482

Letter to the Editor

Unilateral Hematuria Revisited and Reemphasized

Wolfish, N.M.; McLaine, P.N490

Quiz of the Month, Answers

492

Announcement

463

Author Index $\quad 494$

Subject Index 496

Manuscript Consultants

Clinical Papers

Use of Lactate as a Base in Hemodialysis

Nawab, Z.M.; Armstrong, M.K.; Weissberger, L.E.; Ing,

T.S.; Hayashi, J.A.; Daugirdas, J.T 434

Suppl. 1

Calcium Antagonists and the Kidney 